\title{
THE MARIAN EXILE AND RELIGIOUS SELF-IDENTITY: RETHINKING THE ORIGINS OF ELIZABETHAN PURITANISM
}

\author{
ANGELA RANSON" \\ University of York
}

\begin{abstract}
This paper challenges historians' portrayal of Elizabethan puritanism as rooted in the Marian exile of 1553-1558, through a fresh examination of three exiles who have been described as early puritans: James Pilkington, John Jewel, and Laurence Humphrey. By studying the value they placed on church unity, this paper brings out the fundamental differences between the early reformers and the later puritans. It also demonstrates that the religious selfidentity of these men pre-dated the accession of Mary. Thus, their exile was a means of strengthening their faith, not finding it, and their return meant that there was more continuity between the Edwardian and Elizabethan churches than is often allowed in current scholarship.
\end{abstract}

KEY WORDS: Religious self-identity, Protestant, exile, puritan, unity

\section{Introduction}

The reign of the Catholic Mary between 1553 and 1558 often provides a convenient dividing line for the historiography of the English Reformation. The Reformation of Edward VI, which came before it, is portrayed much as is Edward himself: well-meaning and generally sound, but tragically lost far too soon. In contrast, the Elizabethan Reformation which followed Mary's attempt to return to the Church of Rome is described as comparatively slow and awkward, plagued with the problems caused by three major parties. These were: the papists who still adhered to Rome, the conservatives who had managed to remain in England during the Marian years, and the exiles who returned ready to establish a new church that followed the Genevan example.

This portrayal arises from an assumption that many of the English people who went into exile during Mary's reign found their religious self-identity on the continent: a self-identity that is often described as radically, or at least passionately, Protestant. Such a description began with Christina Garrett's

* ANGELA RANSON graduated from the University of York (2014) with her doctorate in early modern English history. Her research focuses on the self-definition of the Church of England in the 16th and 17th centuries. Email: ransoang@gmail.com. 
study of the Marian exiles (1938), which was significantly subtitled: 'A Study in the Origins of Elizabethan Puritanism'. Several decades later, John Neale argued that the Marian exiles were inspired by the reformed churches, and became 'the pressure group of a revolutionary party' in Parliament (1958: 58). In a more recent study of the Elizabethan episcopate, Brett Usher claims that the returning exiles brought in the Calvinist ideas that favoured greater change, and that they found themselves restrained in Parliament by men advocating a slower pace (2003: 4).

From this portrayal evolves the suggestion, found in many studies of the Elizabethan religious settlement of 1559 , that the puritan movement of the 1570 s and 1580s had its genesis in the Marian exile and was fostered during the debates over the establishment of the Elizabethan Church of England. However, on closer examination, some of the church leaders of the 1560s who have been described as 'puritan' to support this portrayal were distinct from the men who gained that label in the 1570s and 1580s, in both their experience and their beliefs. An essential difference between the two groups was the ideal of church unity. Although advocated by Henrican and Edwardian reformers and supported by the early Elizabethans, it was of far lesser importance in the puritan movement.

As this paper will show, the early reformers aimed for unity in the church under the authority of the monarch, even while they fought for an English liturgy, questioned the legitimacy of clerical vestments, and argued for a reformed view of the Eucharist. A decade after the Elizabethan Settlement, new reformers started to question the basic structure and governance of the English Church. At that point, unity became less important than individual conscience. The new reformers began to argue for further reform despite the monarch, and pulled away from the national church.

These different perspectives can be demonstrated by contrasting the arguments of two reformers whose works were published approximately fifty years apart. In 1548, Hugh Latimer chastised England's prelates for not working together to support the king's proceedings in 'setting forth the word and glory of God', which suggests that Latimer saw the monarch as the ultimate leader of reform, although he also expected united action from people in the church (1548: D3v). By 1592, Henry Barrow showed how withdrawal from royal leadership and a national church had advanced. When challenged, he did not deny the suggestion that he and his fellows were removing themselves from communion with the national church because they had decided not to 'tarry for the magistrate'. Rather, he qualified it by saying that they intended to obey God rather than men, saying: 'we are not to stay from doing the Lord's commandment upon the pleasure or offence of any' (1590: B4v-C1). 
It is to the new reformers such as Barrow, the majority of whom had not gone into exile during Mary's reign, that the label of 'puritan' can be more accurately applied. However, that is not to say that it can be easily applied. The danger of over-generalization is high, since not all puritans wanted to separate from the national church in the literal sense. Also, it is a term that has been hotly debated for decades, which made it difficult to settle on a definition for this paper. The most useful choice proved to be from Peter Lake's work Moderate Puritans and the Elizabethan Church. Lake expanded upon a common definition of puritans as 'people who, with varying degrees of intensity, disliked the Elizabethan settlement'. To him, the common ground among puritans could be found in 'an intense vision of the reality and mutuality of the community of the godly, and of the way in which that community could and should be called together through the word, particularly the word preached' (1982: 1, 3).

This provides further clarification for a popular definition by Patrick Collinson, who described puritans as the 'hotter sort of protestants'. Collinson suggested that once this hotter sort returned from the Marian exile, they were embarrassed 'that their Church [bore] small resemblance to the drastically reconstituted churches which they had encountered overseas' (1967: 38). Collinson's description makes a stronger connection between exile and puritanism than does Lake, but both consider the distinct self-identity that characterized the movement. As these and other studies have shown, puritan beliefs encompassed a wide range of theological and political standpoints, but they had one common feature: the idea that they, the godly, were set apart.

This paper will consider the consensus and consistency of other reformers in the church, rather than focusing on the puritan conflict. By examining the call for church unity by the Edwardian and early Elizabethan reformers, it will contribute to the growing field of study which recognizes that Marian exiles and puritans were not necessarily one and the same. It will do this through a fresh study of three exiles often described as holding puritan beliefs on return from exile: John Jewel, James Pilkington, and Laurence Humphrey. They were all part of the reforming movement at the universities before the death of Edward VI, and gained preferment in the early years of Elizabeth's reign. The influence of the continental reformation on these men cannot be denied, but this paper will argue that their migration to the continent did not cause them to develop a vision for church reform along the lines of continental Protestantism, but to refine a vision that had already formed. This will challenge the common assumption that Elizabethan puritanism began in exile, and show the connection between the Edwardian and Elizabethan Reformations.

PERICHORESIS 13.1 (2015) 
First, this paper will examine the major influences on the Edwardian church, and how the actions of these three men during the Marian exile reflected the beliefs they had formed during that time. Then it will take a fresh look at some of their theological works published during the first years of Elizabeth's reign, by examining a theme that all three held in common: God's expectations for returning exiles. As we will see, Humphrey discussed the concept of exile in a general Old Testament context, while both Pilkington and Jewel took on this topic via a parallel with the returning exiles of the Babylonian captivity. Notably, all three men focused on the role of the people in building up God's church, a theme which pre-dated their continental exile.

Through this discussion, this paper will challenge the interpretation of Karl Gunther in his 2009 article 'Rebuilding the Temple', in which he suggested that James Pilkington's commentary on Haggai enabled him 'to denounce the failure of reform and call for the completion of the English Reformation' (2009: 691). Gunther suggests that Pilkington focused on the duty to resist ungodly monarchs, a concern which arose from his time in exile. He finds the seeds of puritan ideas of separation in Pilkington's work, due to one passage regarding the excuses for not rebuilding the temple given by the returning Jewish exiles (2009: 698, 702, 707). This paper will allow a re-interpretation of Pilkington's commentary by placing this passage in its context as a guide for the recovery of a church that had died with Edward VI.

Similarly, a fresh approach to Jewel's sermon on Haggai will enable us to challenge the viewpoint that Jewel was more puritan at heart than he was on paper, due to his experience in exile. Although the term itself is not often used, this portrayal has been in existence since Wyndham Southgate's biography of Jewel (1962: ix). Leonard Trinterud argued that the government used Jewel to counter the papist threat, which effectively distracted him so that the internal reforming zeal inspired by the continental reformation did not turn into external action (1971: 23). More recently, Peter White has suggested that Jewel had a mind for reform which faded away when 'challenged by the extent of English conservatism' (1992: 70), and Gary Jenkins suggests in his biography of Jewel that he had 'sympathies for puritan concerns', which influenced his reactions to the Elizabethan government (2006: 43). However, as this paper will demonstrate, Jewel's Elizabethan sermon on Haggai presented the same message as did a sermon Jewel preached during Edward's reign, which illustrates Jewel's consistency in his ideals of reform and separates him from the beliefs of the puritans.

Laurence Humphrey may well be the easiest of the three men to describe as 'puritan', since he led the argument against the vestments which took place in the mid-1560s. Indeed, many past studies of Humphrey focus on the difficulties his 'puritanism' brought him: Christopher Morris examined the juxtaposition of Humphrey's puritanism and political views (1953: 143-144); 
Paul Welsby connected Humphrey to the puritanism of his college (1962: 6). However, more recent studies of Humphrey have moderated that opinion. Thomas S. Freeman has described him as a 'committed Protestant', and that seems to reflect his beliefs best (Freeman 2004). After his concerted effort for further reform of the church in the 1560s, Humphrey conformed, and separated himself from his more radical colleagues.

The next section of this paper will begin our discussion of these men by examining their Edwardian background. This will include looking at the community of reformers with whom they worked, whose ideas of reform and individual participation influenced them greatly. It will also return to the question of church unity, and its significance during the first years of the English Reformation. This will help show the contrast between these early Elizabethan reformers and the puritans who came after them.

\section{Edwardian Reformers}

The changes in the church during the reign of Edward VI were led in part by the foreign reformers Martin Bucer and Peter Martyr Vermigli. They had been invited to England early in Edward's reign by Archbishop Thomas Cranmer, and given positions as Regius Professors of Divinity: Bucer at Cambridge, and Vermigli at Oxford. The work of these men provided a focal point for the English reformers, because they drew in both controversy and loyalty. At Oxford, Vermigli became the centre of the reforming community, and greatly influenced both John Jewel and Laurence Humphrey. Jewel was a member of the study group that met at Vermigli's home, whose members discussed some of the major religious texts of the day and prepared others for publication (Anderson 1990: 192). Humphrey attended Vermigli's lectures, and was impressed by them. He later recorded that Vermigli had an 'extraordinary ability to teach', and held him up as an example of piety and prudence. He was also was one of those inspired by Bucer's sermons at Cambridge, to the point where he could recall their contents twenty years later (Kemp 1978: 8). Similarly, James Pilkington fondly remembered his friendship with Bucer in a sermon of 1561 (Pilkington 1842b: 651). He became part of what N. Scott Amos calls Bucer's 'circle of Athenians' during his time at Cambridge, just as Jewel became part of Vermigli's study group (2010: 169).

Both Bucer and Vermigli aimed to secure church unity even while they fought for reform. Vermigli's correspondence with Bucer shows how much he wanted to maintain his collaboration with the community of reformers in Cambridge and beyond: in 1551, he wrote that he agreed with what Bucer and Calvin had decided about the Eucharist and intended to support them completely (Vermigli 1989: 341). Bucer, meanwhile, was focused on church unity to the point where he was a cause of conflict. As Diarmaid MacCulloch has noted, his adherence to Cranmer's plan for reconciliation amongst the 
Protestant Churches through compromise did not endear him to the Lutherans (2010: 7). Still, Bucer's advocacy for a moderate pace of reform and the participation of every individual in the church had a long-lasting influence (Amos 2010: 154, 162).

Regardless of the moderate pace, however, the massive changes in the church made unity in the church a major concern at this time. Thomas Becon mourned that 'this peace, this unity, this perfect consent in faith and religion is almost banished from among us in these our days' (1551: lxxi, v). Similarly, Katherine Parr expressed her hope in her Lamentation of a Sinner that contention and strife would be taken away, and 'a godly unity and concord amongst all Christians' sent by God instead (1547: D5r). William Tyndale found someone to blame: he argued that the pope's claim to supremacy destroyed the unity of the church (1548: C1v). This reflects the argument of theologian and ecumenist Paul Avis, who suggests that the reformers believed that 'unity must be in verity', so they 'pitted an apostolic succession of true doctrine against an apostolic succession of unworthy prelates' (2008: 349350).

All of this effort on the part of the reformers had an immediate effect. As Diarmaid MacCulloch has argued, the Edwardian Reformation had a 'driving, unrelenting energy behind it' (1999: 102). Similarly, Felicity Heal argues that the changes taking place during the Edwardian Reformation were enacted 'at a fast and furious pace', and that for the length of Edward's reign 'the development of a wholly reformed church within England had seemed possible' (1980: 203). Massive changes in the doctrine of the church led to massive changes in the fabric of the church. This greatly influenced the clergy and the young men studying to be clergy, including Pilkington, Jewel and Humphrey.

Pilkington was elected as a fellow of St John's College (Cambridge) in 1539, and presented to a living by King Edward sometime between 1547 and 1552 (Marcombe 2004). He was also heavily involved in the Eucharist controversy, taking part in the 1549 disputation of the Eucharist at Cambridge. There he argued passionately for a fully reformed view of the real presence, and denied the entire concept of transubstantiation (Foxe 1583/2011). At nearly the same time, Peter Martyr Vermigli was arguing with William Tresham over the nature of the sacrament at Oxford, and Jewel was one of the notaries recording the debate. He was tasked to write down what was being said while people were speaking, and to act as a legal witness that what was written down was a true representation of what had occurred. Vermigli acknowledged a debt to Jewel in the published version of the debate: in the preface, he praised Jewel's work and expressed gratitude for his help in preparing the manuscript for publication (2000: 4). 
During the reign of Edward VI, Jewel was a fellow of Corpus Christi College. He was known to be a committed reformer, and the extent of his reputation can be seen in his temporary appointment as president of Corpus Christi in 1552. Dr Morwen, the college president, was taken in for questioning by the Council on the charge of using a service other than the prayer book. He was imprisoned, and while he was gone the Council gave Jewel his position, despite his relative inexperience (Strype 1721: 386). One of Jewel's early biographers, Charles LeBas, noted that this was a prestigious appointment for a young scholar, and the involvement of the Council in the decision shows that they had confidence in his loyalty to reform (1835: 18-19).

Significantly, it is likely that Jewel transcribed Vermigli's sermon on the first chapter of Haggai during this time, which dealt with the return of the exiles and God's expectations for them. Vermigli focused on how heinous a sin it was for the exiles to build their own houses and neglect the house of God, thereby placing the onus on the people to repent and participate. He also emphasized that the Holy Spirit would show people what to do as they re-built the temple, which made internal faith and devotion an essential part of belonging to the church (Anderson 1975: 316-317). As we will see, the same message was presented in England after the Marian exile, in Jewel's sermon on Haggai.

Like Jewel, Laurence Humphrey developed a reputation early in his career at Oxford. Most of the records of Humphrey's efforts refer to his resistance to 'papistical rites' and 'popish idolatry' (Kemp 1978: 7). It is likely that this involved reforming the traditional view of the Eucharist. Humphrey recorded an incident from 1549 in the Magdalen college chapel, when the vice-president, Thomas Bickley, manhandled the priest and took away the consecrated host. Humphrey was not shy about his approval of this act (Kemp 1978: 8). Also, in 1552, Humphrey was one of the nine fellows who sent a letter to the royal Council, which denounced the president of Magdalen, Owen Oglethorpe, for maintaining the old faith (Freeman 2004). Oglethorpe resigned soon after, and the reformer Walter Haddon took his place (Kemp 1978: 7).

Of all the controversies underway during the Edwardian Reformation, it seems that Pilkington, Humphrey and Jewel were most involved in the debate over the Eucharist. This debate was consistently concerned with the concept of church unity: reformers such as Thomas Cranmer (1550: 11v), John Frith (1548?: A2), and Miles Coverdale (Calvin 1548: D5-D6) all emphasized the importance of unity for the legitimacy of the sacrament. The participation of these three men in this aspect of reformation, especially by publicly and persistently rejecting the mass, shows how they were already forming a particular religious self-identity. While it cannot be labelled 'Protestant' as yet, it was already distinct from the Catholic Church. 
Significantly, these men accepted the role of the monarch in the church, and they were rewarded for it. Pilkington and Jewel were granted livings, and Humphrey's appeal to royal authority helped gain a new president for his college. As the next section will show, their concept of royal authority in the church would be challenged once Mary I took the throne, but not destroyed. It remained part of their religious self-identity throughout their exile, along with their loyalty to the church of Edward VI.

\section{Marian Exile}

Despite their reputations as reformers, Jewel, Pilkington, and Humphrey were not persecuted immediately after the accession of Mary. This was probably due to their relatively low status, which gave them time before their views were brought to the attention of the authorities. Pilkington left England in 1554: once on the continent, he lived in Zurich, Basle, Geneva, and Frankfurt (Scholefield 1842: ii). Humphrey arrived in Zurich at approximately the same time as Pilkington, but it is not certain when he left England. Jewel left in 1555, and spent his exile in Zurich, Strasbourg, and Frankfurt.

While in exile, all three of these men seemed to have one goal: the unity of the church, which they wanted to see in the unity of the English exiles. As this section will show, this was not something that developed once they arrived on the continent, but arose out of the emphasis on unity that had characterized the Edwardian reformation. Significantly, they also took this goal home with them once Elizabeth took the throne. As William Haugaard has noted, the desire to maintain unity amongst Marian exiles can be best seen in the relationships between the exiles who became Elizabethan bishops and the exiles who had not gained preferment. The bishops 'were reluctant to punish men who had shared the same dangers during the reign of Mary'. They had experienced fear and loneliness together, and so they 'were bound in those unique human bonds that are forged when men choose to face a common adversary for the sake of some great cause' (1968: 230).

The behaviour of the Marian exiles does not align with that of many other exiles of the sixteenth century. Geert Janssen, in his 2012 study of Catholic exiles in the Dutch revolt, suggests that a search for self-identity in the Catholic exiles helped them develop the religious beliefs that had inspired them to leave their country: 'Exile served as a catalyst for radicalisation as it galvanised a more strictly defined, "politicized" confessional mentality' (2012: 680). Katy Gibbons' study of English Catholic exiles in late sixteenth-century Paris also describes the exiles as a 'disparate and fluid group' without a distinct religious identity at first. She argues that it was during the experience of exile that they found common ground in their faith, which strengthened their resistance to Protestantism (2011: 3, 16). In contrast, the Marian exiles were distinct from many of the other exiles of the sixteenth century. As Peter 
Marshall recognizes, their emigration was not a direct result of persecution, since the bulk of the clerical exiles left for Swiss and German Protestant areas in 1553, before the heresy laws had been revived (2007: 267). This suggests that they already had a distinct religious self-identity that they knew would not be acceptable to the new monarch, and chose to leave rather than compromise.

Although Jewel, Humphrey, and Pilkington did not leave with the first wave of exiles, they did begin working for the cause of reform as soon as they arrived on the continent, suggesting that they already had a clear sense of where they fit in. Humphrey was there officially as a student, but he seemed more focused on furthering reform than on his studies. He was also part of a movement for physical as well as doctrinal unity among the exiles. The church at Frankfurt circulated a letter to all the other exiled English faithful, offering to take them in. This sparked a considerable amount of controversy, but the community at Zurich responded positively. Humphrey was one of the men who signed their letter of acceptance, which posited that they ought to join together in aid and comfort, because they were all 'not only of one nation, but also members of one mystical body in Jesus Christ' (Horne 1908: 32$33)$.

The union of congregations did not occur, so Humphrey spent the majority of his exile in Basle. There he worked with John Bale and John Foxe, assisting in the first Latin version of the Acts and Monuments. He continued to work toward maintaining unity amongst the exiles, which came out in his published attempts to moderate the resistance theories of John Ponet and Christopher Goodman. He claimed to be simply expounding the authors' true views, but still contradicted them by advocating only passive resistance (Freeman 2004).

Jewel's work toward unity took several forms during his exile. He maintained his position as secretary for Vermigli, assisting him in researching, editing, and transcribing lectures. These works later emerged as arguments for the reformed view of the Eucharist, against the doctrine of ubiquitarianism, and in support of the role of the magistrate in the church. Perhaps most significantly, Jewel was also part of a delegation who went to Frankfurt in 1555, in an attempt to settle the divisions amongst the exiles there that had been sparked by the aforementioned offer to unite the congregations. Jewel's task was to work with the church leaders and the magistrate in an attempt to find a resolution to the congregation's argument over liturgy and leadership.

They decided that to restore unity they first had to rid the church of John Knox, its intensely zealous leader. To do so, they charged him with high treason against Queen Mary, using evidence from Knox's own writings (Arber 1908: 67). This decision meant that they were upholding Queen Mary's temporal authority over Knox's spiritual authority, even though they considered 
this particular temporal magistrate to be unjust and ungodly. This placed the magistrate in a superior position to the preacher, which applied views on the royal supremacy that reflected those that had developed in the years before the exile.

It was during this conflict that the reformer Richard Cox famously insisted that the exile congregation would 'have the face of an English Church' (Arber 1908: 54). This shows a determination amongst some of the exiles to maintain the standards of later Edwardian reform in both liturgy and leadership, one which Jewel wholeheartedly supported. So did James Pilkington, although he was not part of the original troubles. He arrived in Frankfurt near the end of the Marian exile, and he was there when the news came that Mary had died. Soon after, Christopher Goodman and John Knox, with some of the other more passionate reformers, circulated a letter that advanced their own views on the proper form of the English Church. It called the English exiles to unity against the papists so that the gospel could go forward all the more quickly, and suggested that God had delivered them from 'superfluous ceremonies or other like trifles' during their exile. Since God had shown them the true knowledge of God's word in the best Reformed churches during their 'banishment', the writers of the letter hoped that they would all take that knowledge home for the relief and comfort of 'the members of Jesus Christ' who were already there (Goodman et al 1908: 224-225).

Pilkington was the first one to sign the Frankfurt congregation's reply, and he may have been the penman of it (Scholefield 1842: iii). The reply told Goodman and his fellows that while they too hoped for reform, they would not proceed any further in their Protestant faith than they were 'led by Authority', because 'we trust that both true religion shall be restored, and that we shall not be burdened with unprofitable ceremonies'. It also said, in response to the original letter's advocation of continental styles of worship, that they saw no problem in having diverse ceremonies, so long as they all agreed in unity of doctrine. This letter displays a very Edwardian stance toward reform, papal ceremonies, and the role of the monarch in the church. The development of unity was given the highest importance, and the Frankfurt congregation made it clear that they aimed for restoration, not reformation. They ended the letter with: 'let us, with one heart and mind, call to the Almighty God, that of his infinite mercy he will finish and establish that work that he hath begun in our country' (Pilkington et al 1908: 226).

Thus, it seems that Pilkington, like Jewel and Humphrey, did not develop a distinct religious self-identity that was outside the authority of the crown while in exile, but rather maintained his own Edwardian beliefs throughout. Also, this letter does not reflect the views of later puritans who questioned both the structure of the church and its royal supreme governor. Indeed, even the letter from Geneva that inspired Pilkington's response reflects a 
stronger commitment to church unity than can be found in the puritans of the late Elizabethan church. This puts the first years of the Elizabethan church into context, showing the true diversity of the groups involved in the religious settlement of 1559. Although some reformers returned with a more passionate belief in the structure of the Reformed churches on the continent, others returned with the aim to continue the work that they had started. The next section will show how this diversity affected the Church of England.

\section{Elizabethan Divines}

On their return to England, Pilkington, Jewel, and Humphrey were all given prestigious appointments. Pilkington became the first Protestant Bishop of Durham in 1560, the same year that Jewel became Bishop of Salisbury and Humphrey became Regius Professor of Divinity at Oxford (Scholefield 1842: v). Thus, all three men were all in prime positions to participate in the major religious controversies that threatened to divide the church during its first decade. Significantly, these were much the same controversies that they had dealt with during the reign of Edward. While conflict about the Eucharist was not as prominent, familiar debates over the liturgy, images in the church, and the vestments quickly arose, suggesting that the dividing line between the Edwardian and Elizabethan reformations is not as clear as it may seem. Pilkington was part of the committee for the reform of the liturgy in 1559, although his late arrival from the continent meant that he did not have as much time to contribute as he had hoped (Knappen 1963: 169). Jewel was involved in the controversy over images in the church that arose due to the silver crucifix in the royal chapel, and embarked upon a decade-long defence of the Church of England against the Church of Rome, through a polemical debate with his nemesis, the controversialist Thomas Harding.

All three men became embroiled in the vestments controversy that began in 1564. Humphrey actually led the anti-vestments party, which nearly cost him his position at Oxford (Booty 1963: 13). Pilkington wrote to the Earl of Leicester, asking for his intervention in the matter, because he did not want to see ministers deprived for their apparel when there was such a shortage of preachers (1842c: 659). Similarly, Jewel called the vestments 'the relics of the Amorites' in private, but supported their use in public (1842a: 52). These are the actions that have earned these men their reputations as early puritans, but in actuality their beliefs continued to align with their Edwardian backgrounds.

Pilkington referred Leicester back to Bucer's arguments about the vestments, and hoped that he would remove the last 'stumbling blocks to true religion' (1842c: 662). Jewel felt that, despite the vestments controversy, they were succeeding in the re-establishment of the Edwardian church. In a letter to Vermigli in 1559 , he wrote: 'as to religion, it has been effected... that it 
shall be restored to the same state as it was during your latest residence among us, under Edward' (1842b: 23). Notably, Jewel did not use the term 'reformed', but 'restored'. This suggests that Jewel aimed to return to a religion he had helped establish during the reign of Edward, not develop a new one inspired by his experiences in exile.

He did, however, address the theme of exile in a sermon on Haggai, preached at Paul's Cross. It is not certain exactly when this sermon was preached, because it was published in a collection of sermons in 1583 rather than immediately afterward. However, it was most likely presented in the mid-1560s, approximately four years after Pilkington's commentary on the same Bible passage. In it, Jewel reminded people of the story of the Israelites who had returned from the Babylonian exile and set about restoring their city. Forty years after their arrival, they still had not begun work on the temple. The prophet Haggai was sent to the prince Zerubbabel and the priest Josua to point out that God was angry about their neglect. Both men immediately responded, inspiring the people to stop concentrating their own fine homes and work instead on building up the House of God. Jewel drew an obvious parallel with this story: 'for, as then the city of Jerusalem was miserably razed, and the temple of God burnt down by heathen, even so has it fared in time lately past with the church of Christ here among us' (1847b: 987).

Significantly, Jewel emphasized two aspects of this story: first, the role of Zerubbabel and Darius, the rulers who had made it possible to return and rebuild. This he connected to 'a most noble and virtuous lady', Queen Elizabeth, who was also working to build up the church. Second, he pointed out that it was the people who had to do the building. This reflected the message of Vermigli's Edwardian sermon on Haggai, which also gave the members of the Church of England the responsibility to work together toward the edification of the church. Jewel took this message further by presenting his sermon as a means of helping them fulfil this task. According to Jewel, it was meant to explain the errors and abuses of the Roman church, discuss the excuses that kept people from rebuilding, and show them the kind of church that they should be trying to establish. His focus was very much on showing that the Church of Rome did not reflect the faith of the pure apostolic church, and contrasting it with the faith of the Church of England (1847b: 987-988).

This sermon has a clear link with one Jewel preached during the reign of Edward, perhaps during his ordination service in the early 1550s. In that sermon, Jewel mourned the oppression the church was suffering from the church of Rome and presented the Church of England as representative of the true apostolic faith. Despite the more narrow focus of the Edwardian sermon, both sermons aimed to develop the unity of the English Church by en- 
couraging individual participation. They were also concerned with the restoration of the church. The Edwardian sermon warned that they might lose what they had just recently gained, saying 'our matters are not so firmly established that they cannot fall. Except we take heed, except we look about, except we put to study and diligence, all things will easily slide and fall into their former estate' (1847a: 953). The Haggai sermon acknowledged that they had indeed fallen away, saying that they had strayed far from the original church. However, there was hope: 'let us give God thanks that of his great mercy has restored [the church], and let every man endeavour to re-edifiy it' (Jewel 1847b: 994-995)

Similar themes can be found in Pilkington's commentary on Haggai, published in 1560 and 1562. Pilkington too mourned the loss of the Edwardian church, and wrote to encourage restoration as much as reformation. In the preface, he pointed out that his goal was to further God's true religion, 'of late most mercifully restored to us, which not long ago most cruelly was prosecuted' (Pilkington 1842a: 1). However, where Jewel aimed to connect the English church of Edward's time to the primitive apostolic church, Pilkington focused on the Henrican and Edwardian churches. Like Jewel, he put the onus for the rebuilding of the church on the people. He warned that because the Hebrew people did not appreciate Queen Esther, they were punished with cruel Antiochus. Thus, if the English people did not respond to their current 'mild Esther', namely Elizabeth, they might lose her as they had lost Edward (Pilkington 1842a: 4).

The loyalty to Elizabeth shown in this passage calls into question Karl Gunther's interpretation of Pilkington's puritan-inspired theory of resistance. Gunther suggests that Pilkington placed the blame for the people's failure to rebuild God's house on the rulers' failure to lead them. He contrasts Pilkington's argument to Jewel's sermon, which made the prince Zerubbabel the hero of the piece (2009: 693). However, in this example as in several others Pilkington showed the same loyalty to Elizabeth as did Jewel, driving home the message in several passages that priests were subject to rulers and rulers had to be obeyed. Although Pilkington did allow for resistance in extreme cases, he never wavered from the argument that everyone had their task in the rebuilding of the temple, and an obligation to fulfil it.

Let us do all we can therefore, and pray the Lord to further our work; the rulers with the sword defend the good and punish the evil; the preachers with the word, the school masters by their teaching, the fathers by bringing up their children, the masters by correction of their servants, the people in obeying their heads and neighbourly love; and everyone defend true religion to the uttermost of his power... (Pilkington 1842a: 66). 
Rulers and nobles had their tasks in Pilkington's point of view, and could definitely fail in their obligations. However, the 'the greatest portion is left to every man, which

is his own conscience, to amend that he finds amiss in himself'. The experience of exile should make each person anxious to show their gratitude by working together to build God's house (Pilkington 1842a: 66, 38).

Therefore, for both Jewel and Pilkington, exile was both a punishment and an opportunity. Perhaps more importantly, it was over, and they had to show God that they had learned from their mistakes by a unified attempt at restoring the church. This message can be found in Humphrey's work as well, most specifically in his 'The Preservation of Religion and its True Reformation', which was published in Latin in 1559. Humphrey too pointed out that the English people had not responded quickly enough to the reformation under Edward, and thus they lost him and had to suffer under Mary. He also emphasized that the people themselves had to build up the church, although he did not illustrate his lesson with the story from Haggai.

Instead, Humphrey paralleled the situation of the English church with stories of the mistakes of several Old Testament characters. Like them, the English people had to repent. He brought the message home by saying: 'Christ rejected our church and always rejects it as perfidious and spiritually debauched; nor will he claim his bride except as a chaste and devout virgin. He throws us out as exiles and does not embrace us unless we return to our senses and turn again to ourselves and to him' (Kemp 1978: 178). Again, this demonstrates the expectation for individual repentance and participation, and wholehearted obedience to the monarch as well. Humphrey reminded his audience that Elizabeth was a legitimate and just ruler, placed on the throne by God. 'Now according to the will of God we must obey with the greatest submission we can, the highest vicars of God, kings, princes and magistrates' (Kemp 1978: 196-197).

These three men all presented a message to the people of Elizabethan England that reflected the ideals of the Edwardian church. They each approached it differently, but the emphasis on the individual and the role of the monarch in the church came clearly through in all three. This connects the early Elizabethan church to the Edwardian, in part because they were dealing with the same issues of unity and royal supremacy as they had been a decade earlier. It was only after 1570 that the concerns that had occupied the Edwardian reformers gave way to new challenges, led by men who can be called puritans based on the definition discussed at the beginning of this paper.

These men argued against the very structure and government of the church, and the result was a division between them and many of the exiles. 
Significantly, these men were divided from Humphrey, Pilkington, and Jewel. Even though those three men have all been described as puritan, an examination of their activities shows that they all actively resisted the puritans. Pilkington even called for prayer support from one of the continental reformers as he began the battle: in 1573, he wrote to Rudolph Gwalter mourning over the loss of unity in the church, saying that 'the weak know not what or whom to believe; the godless are altogether insensible to any danger; the Romish priesthood are gaping for the prey' (1842d: 286).

By that time, Jewel was a prominent reformer due to his work as an apologist and a polemicist for the Church of England. He was one of the first to stand against the puritans, preaching a sermon in 1571 that challenged their objections to the established church. In response, the puritan leaders John Field and Robert Wilcox rejected Jewel altogether. They stated publicly that Jewel was in error, saying that he was 'an enemy to sincerity and the truth of Christ's gospel' (Peel 1915: 79-81). Similarly, Laurence Humphrey's desire for further reform clashed with the puritan agenda. He, along with several other Marian exiles, attempted to convince the 1571 parliament to accept a reformed prayer book. This has been seen as a sign of his own puritanism, but significantly his efforts were ruined by a puritan: William Strickland. Thomas Freeman suggests that this failure "may have persuaded Humphrey that further ecclesiastical reform could not be achieved'. It did not, however, draw Humphrey into puritanism. Nor did the efforts of his protégé, John Field. Field attempted to push his puritan agenda by publishing a tract entitled the Admonition to Parliament, and Humphrey could not and did not support that course of action (Freeman 2004).

Perhaps most significantly, many of the puritans themselves did not accept the Marian exiles as part of their movement. In 1573, the prominent puritan Thomas Cartwright firmly rejected them. In his Second Admonition to the Parliament, he said: 'What talk they of their being beyond the seas in Queen Mary's days because of the persecution, when they in Queen Elizabeth these days are come home to raise a persecution.' Cartwright emphasized salvation through hearing the word of God rather than through the liturgy of a national church. He also tried to claim that the Marian martyrs would have agreed with him, saying that if any of them had had the benefit of living amongst the continental reformers, they would have returned with a far better view of church structure than the exiles had (Cartwright 1572: 35). It is evident that Cartwright saw a clear division between the older reformers who had been overseas during the reign of Mary and the new reformers with whom he worked, thus dividing the puritans from the Marian exiles. 


\section{Conclusion}

The three men whose paths we have traced showed a remarkable consistency in their beliefs. They fought the same fight in the 1560s as they had in the early 1550 s, as they attempted to define the royal supremacy and reform the church without sacrificing its unity. The biggest difference was in how they fought, and with whom. That was perhaps the greatest result of their experience with exile.

Through the communities in Zurich, Strasburg and Frankfurt, men such as Jewel, Humphrey and Pilkington developed closer relationships with other English reformers who would later be fellow clerics in the Elizabethan Church of England. This affected how they saw the opportunity presented to them by the accession of Elizabeth. As Diarmaid MacCulloch (1990: 70-71), Joseph McLelland (1957: 41-42) and Philip Hughes all note, the experience at Zurich and Strasburg was completely absorbed into their basic outlooks. Philip Hughes argues that the majority of the reformers who had lived in Strasburg and Zurich emerged from exile 'very conscious that they [were] one in faith with those continental theologians who, in Cranmer's time, had filled the chairs of divinity at Oxford and Cambridge'. Part of this awareness was of their unique definition of what constituted the united church of Christ, and how important it was to convince others to accept their definition (Hughes 1954: 69, 71).

It is evident that exile had a profound effect on the men who left Marian England for the various cities who accepted them on the continent. They gained further education, formed friendships and expanded their experience of reform. Notably, however, they were not all automatically converted to continental worship. Many of them held on to the faith that they had been taught under Cranmer and the community of reformers that he developed during the reign of Edward VI. For these men, exile only encouraged their religious self-identity; it did not create it.

\section{Bibliography}

Amos NS (2010) Protestant Exiles in England: Martin Bucer, the Measured Approach to Reform, and the Elizabethan Settlement. In Wendebourg D (ed) Sister Reformations: The Reformation in Germany and England. Tübingen: Mohr Siebeck, pp. 151-174.

Anderson M (1975) Peter Martyr: A Reformer in Exile. Nieuwkoop: B De Graaf. Anderson M (1990) Vista Tigurina: Peter Martyr and European Reform (1556-1562). The Harvard Theological Review 83(2): 181-206.

Avis P (2008) John Jewel: Anglicanism's Bane or Blessing? Ecclesiology 4(3): 345-355. 
Barrow H (1591) A collection of certaine sclaunderous articles gyuen out by the bisshops against such faithfull Christians. STC (2nd edition) / 1518.

Becon T (1551) The Flower of Godly Prayers. STC (2nd edition) / 1720.3.

Birt HN (1907) The Elizabethan Religious Settlement: A Study of Contemporary Documents. London: George Bell and Sons.

Booty JE (1963) John Jewel as Apologist of the Church of England. London: SPCK.

Calvin John (1548) A faithful and most godly treatise of the most sacred Sacrament. STC (2nd edition) / 4412.

Cartwright T (1572) A second admonition to the parliament. STC (2nd edition)/ 4713.

Collinson P (1967) The Elizabethan Puritan Movement. London: Jonathan Cape.

Cranmer T (1550) Defence of the True and Catholic Doctrine of the Sacrament of the Body and Blood of Christ. STC (2nd edition) / 6000.

Foxe J (1583/2011) The Unabridged Acts and Monuments Online. Sheffield: Online Publications. Available from: http//www.johnfoxe.org, 1408.

Freeman TS (2004) Humphrey, Laurence (1525/7-1589). In Lawrence G (ed) Oxford Dictionary of National Biography. Oxford: Oxford University Press; 2009 online edition.

Frith J (1548?) A Christian Sentence and True Judgement of the Most Honourable Sacrament of Christ's Body and Blood. STC (2nd edition) / 5190.

Garrett C (1938) The Marian Exiles: A Study in the Origins of Elizabethan Puritanism. Cambridge: Cambridge University Press.

Gibbons K (2011) English Catholic Exiles in Late Sixteenth-Century Paris. Chippenham: Boydell and Brewer.

Goodman C et al (1908) The Copy of the Letter, written the 15th of December [1558]. In Arber E (ed) A Brief Discourse of the Troubles Begun in Frankfurt. London: Eliot Stock, pp. 223-225.

Gunther K (2009) Rebuilding the Temple: James Pilkington, Aggeus, and Early Elizabethan Puritanism. The Journal of Ecclesiastical History 60(4): 689-707.

Haugaard W (1968) Elizabeth and the English Reformation: The Struggle for a Stable Settlement of Religion. Cambridge: Cambridge University Press.

Heal F (1980) Of Prelates and Princes: A Study of the Economic and Social Position of the Tudor Episcopate. Cambridge: Cambridge University Press.

Horne R et al (1908) The Answer of the Zurich Exiles. In Arber E (ed) A Brief Discourse of the Troubles Begun in Frankfurt. London: Eliot Stock, pp. 32-33.

Hughes P (1954) Reformation in England, Part Three: 'True Religion Now Established'. London: Hollis and Carter.

Janssen G (2012) The Counter-Reformation of the Refugee: Exile and the Shaping of Catholic Militancy in the Dutch Revolt. The Journal of Ecclesiastical History 63(4): 671-692.

PERICHORESIS 13.1 (2015) 
Jenkins G (2006) John Jewel and the English National Church. Aldershot: Ashgate Publishing.

Jewel J (1842a) John Jewel to Peter Martyr London, Nov 5, 1559. In Robinson H (ed and trans) The Zurich Letters, Comprising the Correspondence of Several English Bishops and Others with some of the Helvetian Reformers, During... The Reign of Queen Elizabeth, first series. Cambridge: Cambridge University Press, pp. 52-54.

Jewel J (1842b) John Jewel to Peter Martyr London, no date. In Robinson H (ed and trans) The Zurich Letters, Comprising the Correspondence of Several English Bishops and Others with some of the Helvetian Reformers, During... The Reign of Queen Elizabeth, first series. Cambridge: Cambridge University Press, pp. 23-25.

Jewel J (1847a) A learned and godly sermon, Latin and English. In Ayre J (ed) The Works of John Jewel, 4 volumes. Cambridge: Cambridge University Press, pp. 2:950-965.

Jewel J (1847b) Haggai I. In Ayre J (ed) The Works of John Jewel, 4 volumes. Cambridge: Cambridge University Press, pp. 2:986-1004.

Kemp JK (1978) Laurence Humphrey, Elizabethan Puritan. PhD Thesis, University of West Virginia, USA.

Knappen MM (1963) Tudor Puritanism: a Chapter in the History of Idealism. Gloucester: Peter Smith.

Lake P (1982) Moderate Puritans and the Elizabethan Church. Cambridge: Cambridge University Press.

Latimer H (1548) A Notable Sermon. STC (2nd edition) / 15291.

LeBas C (1835) The Life of Bishop Jewel. London: JG and F Rivington.

MacCulloch D (2010) Sixteenth-Century English Protestantism and the Continent. In Wendebourg D (ed) Sister Reformations: The Reformation in Germany and England. Tubingen: Mohr Siebeck.

MacCulloch D (1990) The Later Reformation in England 1547-1603. London: MacMillan Education.

MacCulloch D (1999) Tudor Church Militant: Edward VI and the Protestant Reformation. London: Penguin Press.

Marcombe D (2004) Pilkington, James (1520-1576). In Lawrence G (ed) Oxford Dictionary of National Biography. Oxford: Oxford University Press; 2009 online edition.

Marshall P (2007) Religious Exiles and the Tudor State. In Cooper K and Gregory J (eds) Discipline and Diversity. Chippenham: Boydell and Brewer.

McLelland J (1957) The Visible Words of God: An Exposition of the Sacramental Theology of Peter Martyr Vermigli. Edinburgh: Oliver and Boyd.

Milton A (1995) Catholic and Reformed: The Roman and Protestant Churches in English Protestant Thought: 1600-1640. Cambridge: Cambridge University Press. 
Morris C (1953) Political Thought in England: Tyndale to Hooker. London: Oxford University Press.

Neale JE (1958) Elizabeth I and her Parliaments. London: Jonathan Cape.

Parr K (1547) The Lamentation of a Sinner. STC (2nd edition) / 4828.

Peel A (1915) Second Parte of a Register, volumes 1 and 2. Cambridge: Cambridge University Press.

Pilkington J (1842a) Exposition upon the Prophet Haggai. In Scholefield J (ed) The Works of James Pilkington. Cambridge: Cambridge University Press, pp. 1-200.

Pilkington J (1842d) Bp Pilkington to Rudolph Gwalter July 20, 1573. In Robinson H (ed and trans) The Zurich Letters, Comprising the Correspondence of Several English Bishops and Others with some of the Helvetian Reformers, During... The Reign of Queen Elizabeth, first series. Cambridge: Cambridge University Press, pp. 286-289.

Pilkington P (1842b) Sermon on Bucer and Phagius (1560). In Scholefield J (ed) The Works of James Pilkington. Cambridge: Cambridge University Press, pp. 651-657.

Pilkington P (1842c) Letter to the Earl of Leicester. In Scholefield J (ed) The Works of James Pilkington. Cambridge: Cambridge University Press, pp. 658-662.

Pilkington P et al (1908) The Reply of the Anglican Church at Aarau. In Arber E (ed) A Brief Discourse of the Troubles Begun in Frankfurt. London: Eliot Stock.

Primus JH (1960) The Vestments Controversy. Amsterdam: JH Kok.

Scholefield J (1842) The Works of James Pilkington. Cambridge: Cambridge University Press.

Southgate W (1962) John Jewel and the Problem of Doctrinal Authority. London: Oxford University Press.

Strype J (1721) Ecclesiastical memorials; relating chiefly to religion, and the reformation of It. Oxford: Clarendon Press.

Trinterud L (1971) Elizabethan Puritanism. New York, NY: Oxford University Press.

Tyndale W (1548) The Practyse of Prelates. STC (2nd edition) / 24467.

Usher B (2003) William Cecil and Episcopacy, 1559-1577. Aldershot: Ashgate Publishing.

Vermigli PM (1989) In McLelland JC and Duffield G (eds) The Life, Early Letters and Eucharistic Writings of Peter Martyr. Abingdon: Sutton Courtenay Press.

Vermigli, PM (2000) In McLelland JC (trans and ed) The Oxford Treatise and Disputation of Peter Martyr. Kirksville, MO: Sixteenth Century Essays and Studies.

Welsby P (1962) George Abbot: the Unwanted Archbishop. London: SPCK.

PERICHORESIS 13.1 (2015) 
White P (1992) Predestination, Policy and Polemic: Conflict and Consensus in the English Church from the Reformation to the Civil War. Cambridge: Cambridge University Press. 